\title{
LA IMPRESCRIPTIBILIDAD DE LOS DELITOS CONTRA LA LIBERTAD E INDEMNIDAD SEXUAL EN EL PERÚ
}

\section{THE IMPRESCRIPTIBILITY OF CRIMES AGAINST FREEDOM AND SEXUAL INDEMNITY IN PERU}

\author{
Alexei Dante Sáenz Torres ${ }^{1}$ \\ Docente \\ Universidad Nacional Mayor de San Marcos \\ alexeisaenz@gmail.com \\ Perú, Lima
}

\section{SUMARIO}

- Introducción

- Antecedentes de la reforma

- Precedentes de derecho comparado

- Técnica legislativa

- Análisis del artículo 88-A: La imprescriptibilidad

- La problemática del artículo 5 de la Ley $\mathrm{N}^{\circ} 30096$, delito de ciber acoso infantil o child grooming luego de su modificación mediante la Ley $\mathrm{N}^{\circ} 30838$

- Concurso e imprescriptibilidad

- Conclusiones

\section{RESUMEN}

El presente artículo tiene por finalidad analizar los aspectos positivos y negativos de la Ley $\mathrm{N}^{\circ}$ 30838, mediante la cual se incorporó por primera vez al Código Penal de 1991 la imprescriptibilidad de los delitos contra la libertad sexual, indemnidad sexual y otros delitos conexos, así como establecer los alcances de la reforma en el sistema penal peruano.

\section{ABSTRACT}

The purpose of this article is to analyze the positive and negative aspects of Law $\mathrm{N}^{\circ} 30838$, by means of which the imprescriptibility of crimes against sexual freedom, sexual indemnity and other related crimes was incorporated for the first time into the 1991 Penal Code. How to establish the scope of the reform in the Peruvian penal system.

\section{PALABRAS CLAVE}

Imprescriptibilidad; Delitos contra la libertad sexual; Delitos contra la indemnidad sexual.

\section{KEYWORDS}

Imprescriptibility; Crimes against sexual freedom; Crimes against sexual indemnity.

\section{INTRODUCCIÓN}

La cantidad de agresiones y abusos sexuales que sufren los niños, niñas, adolescentes mujeres adultas en el Perú, ha significado la justificación de la aprobación y entrada en vigor de la Ley $\mathrm{N}^{\circ} 30838$. Las recientes cifras de condenados tratándose de menores de edad, aspecto principal de la justificación de la presente reforma, arrojan que se tiene más de 8 mil presos por agresiones sexuales (Fernández, 2018), así como se ha dado a conocer que en el año 2020 saldrán en libertad 717 presos por agresión sexual (Milagros Berríos, 2018).

El tema como propuesta y discusión no es nuevo, incluso se asumió en varios períodos legislativos las promesas electorales como una suerte de iniciativa populista o como una manifestación del populismo jurídico, aunque sus mentores todavía no se terminan de poner 1 Profesor Principal en la UNMSM en el pregrado y el posgrado, profesor contratado en la Escuela de Posgrado de la USMP y profesor
contratado en la UNFV y en la AMAG. 
de acuerdo respecto al concepto, así como su delimitación, dependiendo de la ideología asumida.

En alguna ocasión, dentro de este panorama, resultó interesante lo señalado por Rivera García (2018) al decir:

Nos encontramos ante el dificilísimo reto de construir un Estado de derecho que, sin caer en lo males derivados del populismo teorizado por Laclau, sea el resultado de unir dos conceptos que, para el pensamiento político moderno, han sido esencialmente incompatibles: el estable poder constituido y el innovador poder constituyente. (página 72)

Así al tratar este tema, inicialmente desdeñado o dejado de lado por la ciencia penal, hoy en día, a la luz de las noticias de casos denunciados, sobre todo teniendo como víctimas a menores de edad y adolescentes, e incluso con resultados de muerte, ha significado reconocer una impunidad que no se puede mantener, por ello ahora que se ha regulado rápidamente es una obligación de la academia discutir sus alcances y deficiencias.

En torno a la justificación o no de la imprescriptibilidad resulta interesante lo postulado por Manuel Cerrada Moreno (2018), quien, reconociendo el efecto simbólico de la imprescriptibilidad, sin embargo, señala al referirse al aspecto interno de la regulación española que:

Incluso desde el punto de vista de la dogmática jurídico-penal, una vez admitida como necesaria la existencia de un sistema penal que excluya la venganza privada y en el que se tipifiquen como delitos distintas acciones atendiendo a diversas consideraciones de Política criminal, si se considera que la posibilidad de prescripción no es una previsión obligatoria en todo sistema jurídico, sino una cualidad de cada delito que, en atención a tales principios pude ser establecida o excluida por el legislador soberano (democráticamente elegido) para cada tipo penal, sin perjuicio de que puedan establecer también previsiones en atención al posterior comportamiento del delincuente, la imprescriptibilidad legalmente prevista en el seno de ese ordenamiento jurídico, considerado legítimo, pueden fundarse simplemente en la falta de razón así apreciada por el legislador para limitar temporalmente la posibilidad de castigar a los responsables de los crímenes de mayor gravedad, o a los responsables de otros crímenes que no hayan dado muestras, con hechos posteriores a su comisión, de merecer el beneficio de la prescripción. Y ello, incluso con independencia de que se trate o no de crímenes reconocidos como imprescriptibles en el Derecho internacional. (Páginas 461-462)

Para ello, a continuación, se evaluará brevemente los aportes de la doctrina y el derecho comparado en torno a la imprescriptibilidad ${ }^{2}$ de los delitos de agresión sexual, abuso sexual y similares, como se aprecia antes solo se discutía en torno a los fundamentos positivos y negativos como lo señaló el maestro Luis Eduardo Roy Freyre (2018).

\section{ANTECEDENTES DE LA REFORMA}

En la anterior legislatura se presentaron diversos proyectos de ley que pretendieron regular la opción de evitar que los delitos de agresiones y abusos sexuales realizado contra menores de edad no prescriban, en esos momentos la legislación comparada presentaba tres modelos bien definidos, el primero el de la ampliación de las penas con su efecto inmediato, la ampliación de los plazos de prescripción; el segundo, el de la prescriptibilidad, acudiendo a la suspensión de los plazos de la prescripción penal; el tercero, el modelo de la imprescriptibilidad (en sus modalidades: reducida o ampliada); y el cuarto, el modelo mixto.

\section{Primer modelo}

Hasta antes de esta última reforma, el Estado apostó constantemente en las modificaciones penales de los diversos delitos al incrementar los montos de las penas privativas de la libertad. Lo mismo se aplicó en las modificaciones de los delitos de agresión sexual contra menores

2 Al respecto los fundamentos de la imprescriptibilidad véase la p. 249 y siguientes de nuestra tesis para optar el grado de magister donde tuve el honor de tener al Dr. Luis Eduardo Roy Freyre como parte del jurado examinador, de la tesis titulada: La prescripción penal en el Perú (a veinte años de vigencia del Código Penal de 1991), en el enlace: http://cybertesis.unmsm.edu.pe/bitstream/handle/cybertesis/7980/Saenz_ta.pdf?sequence $=1$ \&isAllowed $=y$ 
e indemnidad sexual en el perú

The imprescriptibility of crimes against freedom

and sexual indemnity in peru

de edad y adolescentes, el cual mantenía la lógica de tener el modelo de la prescripción, basado en el criterio de los plazos máximos tratándose de las penas privativas de la libertad que permitió el sistema penal.

Sin embargo, ello no significó una barrera para la realización de los delitos, pues día a día se siguió reportando casos de infracciones penales contra niños y adolescentes, por ello se empezaron a presentar propuestas de ley para evitar lo que socialmente se apreció como una impunidad de este tipo de delitos.

Es claro que en la primera década del siglo XXI, no se tenía reportes de la magnitud de realización de este tipo de delitos en contra de menores de edad y adolescentes, empero en la actualidad esto ha variado respecto al siglo anterior y a la década pasada, pues ahora se tiene conciencia que muchas veces el violador no es un extraño, sino un pariente que está en el mismo ambiente en el que vive o desarrolla sus actividades (colegio, cunas, hospicios, asilos, academias, clubes de vacaciones útiles, academias deportivas, iglesias, grupos, etc.).

\section{Segundo modelo}

El segundo modelo permite extender el plazo de prescripción de la acción penal y de la ejecución de la pena, el cual se manifiesta en una de sus variantes como el del modelo español, es decir la suspensión del plazo de la prescripción mientras la víctima menor de edad no alcance la mayoría de edad, que en el caso del Perú es a los dieciocho años, aunque este modelo fue seguido por algunos países de América del Sur y Centro América (Argentina art. 67 del Código Penal, Bolivia art. 475. II del Código Penal de Bolivia referido a los procedimiento penales, Chile art. 369 quater del Código Penal y Paraguay en sus artículos 103.1 punto 2$)^{3}$ y en Europa el caso de España (art. 132.1 segundo párrafo del Código Penal).

3 Véase el Informe Temático No 13/2017-2018 realizado por Elena Alarcón Hermosa para el Congreso de la República de Perú en torno a los países que regularon penalmente las fórmulas de suspensión de la prescripción condicionadas al cumplimiento de la mayoría de edad de la víctima para delitos contra la libertad sexual y otros (Colombia art. 83.3 del Código Penal, Costa Rica en el art. 31 y 33 del Código Procesal Penal, El Salvador en el art. 99.1 del Código Penal, México en el art. 107-Bis del Código Penal Federal, Nicaragua art. 131 del Código Penal, aunque con la modalidad de condicionar el plazo de inicio de la prescripción penal bajo los alcances de la inmunidad para los menores de edad y Panamá en el art. 93 del Código Penal delitos contra el pudor, integridad y libertad sexual de menores, incapaces o persona con discapacidad a partir que cumplan la mayoría de edad, en el enlace:

http://www2.congreso.gob.pe/sicr/cendocbib/con5_uibd.nsf/75C210 AA031030F 1052581C600789CC2/\$FILE/InformeTem\%C3\%A1ticoImprescriptibilidadFINAL.pdf
Así siguiendo a los modelos del derecho comparado, en el Perú se formularon algunas propuestas que van en esta dirección, como son las presentadas por el Grupo Parlamentario de Fuerza Popular proyecto de ley $\mathrm{N}^{\circ}$ 2013/2017-CR, el Grupo Parlamentario Nuevo Perú proyecto de ley $\mathrm{N}^{\circ} 2258 / 2017-\mathrm{CR}$, y el Grupo Parlamentario Fuerza Popular mediante el proyecto de ley $\mathrm{N}^{\circ} 1989 / 2017-\mathrm{CR}$, y el proyecto de ley $1022 / 2016-\mathrm{CR}^{4}$.

\section{Tercer modelo}

En cambio, el tercer modelo deja de lado la prescripción y se enmarca en la imprescriptibilidad de la acción o persecución penal, así como en la ejecución de la pena, modelo que han seguido varios países sudamericanos, algunos en el plano constitucional (Ecuador art. 46.4) y otros solo en el plano legal (caso del Perú y aún en debate Chile).

La opción de la imprescriptibilidad, tanto desde la perspectiva constitucional como la legal, se formularon las siguientes iniciativas legislativas por parte del congresista Modesto Figueroa Minaya 3008/2017-CR Grupo Parlamentario Alianza para el Progreso 2485/2017-CR, Grupo Parlamentario Aprista 2305/2017-CR, Grupo Parlamentario Frente Amplio proyecto de ley 2070/2017-CR, el congresista Moisés Bartolomé y otros proyecto de ley 1602/2016-CR, Grupo Parlamentario Peruanos por el Cambio proyecto de ley $\mathrm{N}^{\circ}$ 1396/2016-CR, el congresista Migue Román Valdivia 1164/2016-CR, Grupo Parlamentario Frente Amplio proyecto de ley 1069/2016CR, Grupo Parlamentario Aprista proyecto de ley $N^{\circ} 1037 / 2016-C R$, Grupo Parlamentario Fuerza Popular proyecto de ley $\mathrm{N}^{\circ} 1022 / 2016-$ $\mathrm{CR}$, el congresista Carlos Bruce proyecto de ley $N^{\circ}$ 4954/2015-CR, Grupo Parlamentario Alianza Parlamentaria proyecto de ley $\mathrm{N}^{\circ}$ $1063 / 2011-\mathrm{CR}^{5}$.

Sin embargo, el debate en la academia aún no se había iniciado, ahora la entrada en vigor de la Ley $\mathrm{N}^{\circ} 30838$, en lo que a la imprescriptibilidad se refiere, el debate recién se va a iniciar. Todavía algunos discuten si el plazo de la prescripción estipulado por el Código Procesal Penal era de interrupción y no de suspensión de la prescripción? o ¿suspensión y no interrupción?), por lo cual habría que considerar los efectos que hubiese

4 Véase el anexo $\mathrm{N}^{\circ} 10$ del presente artículo.

5 Véase el anexo $\mathrm{N}^{\circ} 10$ del presente artículo. 
generado la fórmula que más países regularon en sus legislaciones como fue la fórmula de la suspensión hasta que el menor alcanzara la mayoría de edad, es decir los 18 años.

\section{Cuarto modelo}

El cuarto modelo trata de aquellos países que regulan la prescripción como regla general para la mayoría de infracciones penales y excepcionalmente la imprescriptibilidad para un grupo de delitos considerados de mayor gravedad. Así se tienen las variantes reducidas y ampliadas.

La versión reducida se manifestó solo para casos de delitos de lesa humanidad (genocidio), teniendo como fuente el derecho internacional público (a través de diversos tratados y convenciones) y luego el derecho penal internacional (el tratado que reguló la aprobación de la CPI: Además de lesa humanidad, incluyó crímenes de agresión, genocidio y crímenes de guerra), con su influencia en la adecuación de la legislación interna de algunos países firmantes.

La otra versión es la ampliada y en progreso, que comprende además de los delitos de lesa humanidad, asesinato, corrupción, agresiones y abusos sexuales contra menores, así como secuestro de menores, medio ambiente, terrorismo con resultado de muerte, entre otros ${ }^{6}$.

Indudablemente esta tendencia se ve justificada por distintas razones que sancionan las infracciones a la seguridad ciudadana, al orden interno de un país, al terrorismo interno e internacional, a las agresiones y abusos a

6 Al respecto el vigente Código penal de Suiza estableció en su artículo 101: "Art.101.- Imprescriptibilidad.

1. No existe ninguna limitación del derecho a enjuiciar a los delitos de:

a. El genocidio (art. 264);

b. Crimenes de lesa humanidad (art. 264a párrafo 1 y 2.);

c. Crimenes de guerra (art. 264c párrafo 1-3, 264d del párrafo 1 y $2,264 \mathrm{e}$ del párrafo 1 y $2,264 \mathrm{f}, 264 \mathrm{~g}$ del párrafo 1 y 2 y 264 h);

d. Delitos graves que hayan causado o amenaza causar un peligro para la vida y la integridad fisica de un gran número de personas como un método de extorsión o coacción, en particular mediante el uso de medios de destrucción masiva, la causa de las catástrofes, o como parte de una toma de rehenes delito.

2. Si el derecho de perseguir el delito habría sido prescrito tenía los artículos 97 y 98 aplicadas, el Tribunal podrá a su discreción, imponer una pena más leve.

3. Los apartados 1 letras A, C y D y el apartado 2 se aplican si el derecho de enjuiciar o ejecutar la sentencia no habrian prescrito al $1^{\circ}$ de enero de 1983 , en conformidad con la legislación vigente hasta ese momento.

El apartado 1 letra b se aplica si al momento de la entrada en vigencia de la enmienda o modificación del 18 de junio de 2010 de la presente ley, la acción penal o la pena no habia prescrito en virtud de la ley hasta en aquel entonces vigente". menores de edad, a los atentados al medio ambiente, a las distintas infracciones reguladas en el Estatuto Penal de Roma, por citar los casos más relevantes, lo cual significa que la discusión sobre la imprescriptibilidad irá in crescendo.

\section{PRECEDENTES DE DERECHO COMPARADO}

A lo largo de la historia de las legislaciones, la regulación de la imprescriptibilidad penal fue postulada en uno de los primeros códigos como fue el Código para el Gran Ducado de Toscana en su art. 95 que estipuló "contra las condenas no se dará prescripción". De allí en adelante esta fórmula genérica se ha ido poco a poco expandiendo en los diversos códigos en la actualidad como más adelante se verá?

En adelante las fórmulas de la imprescriptibilidad recién se volvieron a discutir luego de la posguerra de la II Guerra Mundial, a propósito de los delitos atroces cometidos por los ejércitos alemán e italiano, así como otros conflictos posteriores.

Empero, en materia de imprescriptibilidad para delitos de agresión sexual contra niños, adolescentes y ahora demás víctimas de estos delitos y otros similares, se aprecian una serie de puntos desde la perspectiva comparada como a continuación se apreciará.

\section{El caso de Chile ${ }^{8}$ :}

El viernes 05 de mayo del 2018 en Chile al asumir su nuevo mandato el presidente Sebastián Piñeira firmó el proyecto que regula la imprescriptibilidad de los delitos de violación sexual de menores de edad en Chile señalando: "El Jefe de Estado precisó que la

7 En el Perú se aprecia el antecedente más remoto de manera genérica y referido a las penas en el Proyecto de Vidaurre Ley 31 que señaló "Los crímenes no reiterados prescriben a los tres años: los atrocismos a los diez: la acción civil a los veinte: no hay prescripción, si hubo sumaria por acusación o delación", y el Anteproyecto de Código Penal de 1927 art. 70 , donde se señala que las penas de presidio e inhabilitación perpetua no prescriben en ningún tiempo (21).

8 En Suiza se propuso la reforma constitucional por parte de Marche Blanche, sin embargo fue rechazada por ambas cámaras así uno de los argumentos fue: "que los delitos más graves, como el homicidio o incluso el infanticidio, seguirían siendo prescriptibles, ya que la legislación actual solo haría tres excepciones: crímenes de guerra, crímenes contra la humanidad y atentados terroristas", (Comisión de Constitución, Legislación y Justicia de la Cámara de Diputados, Boletín $\mathrm{N}^{\circ} 8134$ titulado "Imprescriptibilidad de acciones civiles y /o penales por delitos sexuales contra menores de edad en el derecho comparado, véase:

https://webcache.googleusercontent.com/search?q=cac he:6hEifmaiwWoJ:https: //www.bcn.cl/obtienearchivo $\%$ 3Fid\%3Drepositorio/10221/23428/2/imprescriptibilid ad\%2520de\%2520abuso\%2520sexual\%25202016_eval. pdf $+\& c d=1 \& h l=$ es $-419 \& \mathrm{ct}=\mathrm{clnk} \& \mathrm{gl}=\mathrm{pe}$ 
e indemnidad sexual en el perú

The imprescriptibility of crimes against freedom

and sexual indemnity in peru

iniciativa tiene como fin que los niños que han sido abusados sexualmente ejerzan su defensa para que se puedan recuperar y hacer justicia" (teleSUR, 2018, párrafo 5).

Esta iniciativa se debió a la indignación de la sociedad chilena tras el hecho de la violación de una bebé de nombre Ámbar "una niña de un año y ocho meses que murió por una presunta violación y posterior golpiza"(teleSUR, 2018, párrafo 4$)^{9}$.

Como se sabe para la legislación penal chilena que utiliza el modelo del plazo legal, los delitos prescriben luego de transcurrir el plazo de prescripción ordinaria.

Lo que se propone es establecer que el plazo de prescripción de la acción penal para los delitos leves con penas menores de cinco años, cuyo plazo de prescripción era de cinco años se suba a veinte; y para los delitos con penas de cinco a más años cuyo plazo de prescripción es de diez años, ahora serían imprescriptibles, dentro de los cuales se encuentran los delitos de violación sexual contra menores de edad.

$\mathrm{Al}$ respecto hay que diferenciar los casos de prescripción de la acción penal y los plazos de la prescripción de la pena. Para ello, tenemos que acudir a los artículos 94 y 97 del CP de Chile.

En el caso de prescripción de la acción penal se establecen tres casos, los delitos leves con penas inferiores a cinco años, los delitos con penas de cinco a más años y los crímenes con penas de quince a más años. Para el primer caso el plazo de prescripción vigente es de cinco años, para el segundo caso de diez años y para el tercer caso de quince años.

Sin embargo, en Chile ya han pasado tres meses y aún los congresistas chilenos siguen discutiendo la propuesta de la imprescriptibilidad pena para los delitos de violación sexual contra menores de edad donde como fundamentos se han postulado el

\footnotetext{
9 Así mismo también en Chile se han realizado algunos trabajos sobre la imprescriptibilidad así véase:

https: / / abusosexualimprescriptible.cl/wp-content/ uploads / 2018/07/Derecho-al-Tiempo-Propuestas-deIndicaciones-junio-2018.pdf

https:// webcache.googleusercontent.com/search?q=cac he:6hEifmaiwWoJ:https://www.bcn.cl/obtienearchivo\% 3Fid\%3Drepositorio/10221/23428/2/imprescriptibilid ad\%2520de\%2520abuso\%2520sexual\%25202016_eval. $\mathrm{pdf}+\& \mathrm{~cd}=15 \% \mathrm{hl}=\mathrm{es}-419 \& \mathrm{ct}=\mathrm{clnk} \& \mathrm{gl}=\mathrm{pe}$

En el Perú en el siglo pasado en la década de los noventa hubo un caso similar como lo fue el Caso Beto, ocurrido en el Puericultorio Pérez Aranibar.
}

desarrollo cerebral, cognitivo y epigenética del abuso infantil y adolescente ${ }^{10}$.

Por ahora, habrá que esperar si el Congreso de Chile decide aprobar esta iniciativa presentada por el Poder Ejecutivo.

\section{TÉCNICA LEGISLATIVA}

La técnica legislativa hoy sigue siendo de relevancia, pues cuando mejor se ha aplicado esta se evitarán interpretaciones erróneas, de allí que se "ocupa de aspectos formales de las leyes (lenguaje, estructura, sistemática), sino también de que éstas cumplan los objetivos perseguidos con su aprobación, esto es, que la regulación sea materialmente adecuada" (García-Escudero Márquez, 2011, página 73).

En este sentido la evaluación normativa "es la verificación del grado de cumplimiento de los fines y resultados de una ley o de una política pública, mediante un conjunto de técnicas que permitan un análisis sistemático" (GarcíaEscudero Márquez, 2011, página 73). Tanto ex post como ex ante será una necesidad apenas se vea si los jueces penales la aplican o no, y cómo la aplican, situación que por ahora no se puede responder, pero sí postular.

A continuación, se analizarán los alcances de la regla jurídica.

\section{Por su ubicación}

Uno de los puntos a analizar desde la perspectiva de la técnica legislativa es el hecho de haber regulado en el art. 88-A del Código Penal, dentro de los alcances de la prescripción de la pena, lo propio hubiese sido regularla en el art. 80 in fine, y de paso se aprovechaba la ocasión para regular la imprescriptibilidad de los delitos contra la administración pública, y luego regularla en el art. 85 in fine expresamente $^{11}$, pero aquí queda plasmado

\footnotetext{
$10 \mathrm{Al}$ respecto es interesante lo señalado en el Derecho al tiempo. Fundamentos y Propuestas para la Imprescriptibilidad de la Acción Penal respecto a delitos de agresión sexual contra niños, niñas y adolescentes, 12 de abril de 2018 , p. 5 y ss., véase en el enlace:

https: / / abusosexualimprescriptible.cl/wp-content/ uploads /2018/04/Propuesta_ASI_Imprescriptible_-_ Abril-2018_con-resumen_2.pdf

11 Los argumentos en torno a la reforma constitucional están señalados en el artículo titulado "La prohibición de la prescripción o la imprescriptibilidad como reforma penal inconstitucional", publicado en la Revista Vox Juris $\mathrm{N}^{\circ} 36$ (2): 147-161, 2018:

https://www.aulavirtualusmp.pe/ojs/index.php/VJ/ article/viewFile/1312/pdf12
} 
la falta de voluntad de los congresistas para legislar adecuadamente.

De allí que el legislador se apresuró en regular la imprescriptibilidad en un lugar inapropiado y carente de coherencia, pues se pierde toda conexión, tan igual como si se hubiese regulado en la parte final de los delitos contra la libertad sexual y otros tipos conexos contra la libertad. o si se hubiese colocado como último párrafo en cada delito declarado imprescriptible.

\section{La comunicación de la imprescriptibilidad}

Otro de los problemas del art. 88-A es el haber utilizada la formula lacónica que no inspira o comunica nada a los potenciales autores o víctimas de los delitos declarados imprescriptibles, no cumpliendo con su finalidad de prevención general, por lo cual mejor hubiese sido redactar un artículo que incluya expresamente el nomen iuris de cada artículo con su respectivo numeral, como a continuación se sugiere.

Los delitos comprendidos por el art. 88-A del Código Penal (Ley $\mathrm{N}^{\circ} 30838$, art. 2 ab initio) son la trata de la persona (art. 153), las formas agravadas de la trata de personas (art. 153-A), la explotación sexual (art. 153-B), la esclavitud y otras formas de explotación (art. 153-C), la violación sexual (art. 170), la violación de persona en estado de inconsciencia o en la imposibilidad de resistir (art. 171), la violación de persona en incapacidad de dar su libre consentimiento (art. 172), la violación sexual de menor de edad (art. 173), la violación de persona bajo autoridad o vigilancia (art. 174), la violación sexual mediante engaño (art. 175), los tocamientos, actos de connotación sexual o actos libidinosos sin consentimiento (176), los tocamientos, actos de connotación sexual o actos libidinosos en agravio de menores (art. 176-A), las formas agravadas de los delitos regulados en los artículos $170,171,172,173$, $174,175,176$ y 176-A. Además, se incluye a los delitos de favorecimiento a la prostitución (art.179), el usuario-cliente (art. 179-A), el rufianismo (art. 180), el proxenetismo (art. 181), la explotación sexual comercial infantil y adolescente en ámbito del turismo (art. 181-A), las formas agravadas de los delitos regulados en los artículos 179, 181 y 181-A, la publicación en los medios de comunicación sobre delitos de libertad sexual a menores (182-A), las exhibiciones y publicaciones obscenas (art. 183), la pornografía infantil (art. 183-A), y las proposiciones a niños, niñas y adolescentes con fines sexuales (art. 183-B).

Sin embargo, a estas reformas realizadas por el Congreso de la República a través de la Ley $\mathrm{N}^{\circ} 30838$ en el mes de agosto, un mes después vía legislación delegada, el Poder Ejecutivo ${ }^{12}$ aprobó y publicó el Decreto Legislativo $\mathrm{N}^{\circ}$ 1410 , por el cual se introdujo por primera vez en la legislación peruana, los delitos de acoso (art. 151-A), difusión de imágenes, materiales, audiovisuales o audios con contenido sexual (art. 154-B), acoso sexual (art. 176-B) y el delito de chantaje sexual (art.176-C), aunque estos delitos, al haber sido incorporados con posterioridad a la entrada en vigencia de la ley $\mathrm{N}^{\circ} 30838$, hoy no son imprescriptibles.

$\mathrm{Al}$ parecer esto no es un error, sino más bien se traduce en el enfrentamiento entre el Congreso de la República y el Poder Ejecutivo, que como antecedente ya se había mostrado con el tema de la rehabilitación penal (art. 69 del Código Penal), en donde el Poder Ejecutivo aprobó el Decreto Legislativo $\mathrm{N}^{\circ} 1367$, mediante el cual reguló en su artículo 1, algunos supuestos de la rehabilitación penal (art. 69 del Código Penal) para delitos graves, empero días después el Congreso a través de la Ley $\mathrm{N}^{\circ} 30838$, art. 1, por el cual se modificó la rehabilitación penal (art. 69 del Código Penal), restringiendo y derogando algunos supuestos referido a algunos delitos graves, por lo cual el Poder Ejecutivo tuvo que volver a aprobar un nuevo Decreto Legislativo $\mathrm{N}^{\circ} 1453$, mediante el cual integró lo regulado mediante el Decreto Legislativo $\mathrm{N}^{\circ} 1367$, con lo dispuesto por la Ley $\mathrm{N}^{\circ} 30838$, pero de todas maneras creo una incertidumbre en los que casos ocurridos entre el 05 de agosto del 2018 y el Decreto Legislativo $\mathrm{N}^{\circ} 1453^{13}$.

12 El Congreso de la República aprobó la ley $\mathrm{N}^{\circ} 30823$, por el cual cedió su atribución de legislar en los temas de protección y prevención de personas en situación de violencia y vulnerabilidad, asi se establece en el punto $\mathrm{N}^{\circ}$ 4), dispuso "Modificar la Ley 29360, Ley del Servicio de Defensa Pública. Así como legislar en materia de prevención y protección de las personas en situación de violencia y vulnerabilidad contempladas en el artículo 3 del Decreto Legislativo 1098, Decreto Legislativo que aprueba la Ley de Organización y Funciones del Ministerio de la Mujer y Poblaciones Vulnerables, a fin de: (...)

b) Fortalecer el marco jurídico para la prevención y protección de violencia contra la mujer y grupo familiar, asi como de víctimas de casos de acoso, acoso en espacios públicos, tentativa de feminicidio, feminicidio, violación sexual y violación sexual de menores de edad, así como para la sanción efectiva ante la comisión de dichos delitos. Crear el Sistema Nacional Especializado de Justicia para la Protección y Sanción de Violencia contra las Mujeres e Integrantes del Grupo Familiar".

13 Este decreto legislativo $\mathrm{N}^{\circ} 1453$ se publicó el 16 de setiembre 
Ahora, esto vuelve a suceder, pero el error se atribuye al Poder Ejecutivo, razón por la cual cuando el Congreso de la República tenga que realizar la evaluación de las facultades notará el error y tendrá que corregir a través de una nueva iniciativa legislativo en el que incluya los delitos de acoso (art. 151-A), difusión de imágenes, materiales, audiovisuales o audios con contenido sexual (art. 154-B), acoso sexual (art. 176-B) y el delito de chantaje sexual (art.176-C).

\section{La redacción de los presupuestos y consecuencias}

Los modelos de regulación tanto de la prescripción como de la imprescriptibilidad dependen de la redacción realizada por el legislador, de tal manera que la utilización de fórmulas directas o expresas, así como de fórmulas indirectas o tácitas se tienen que realizar con sumo cuidado y se deben apreciar antes de aprobarse a fin de evitar efectos o consecuencias no queridos y mensajes contrarios a la prevención general.

\section{Fórmulas directas}

Se denominan directas en el sentido de la técnica legislativa, pues cada vez que el legislador quiera realizar modificaciones a una institución jurídica, se tendrá que modificar el texto materia de la reforma (sea agregando, suprimiendo, separando, diferenciando supuestos).

En otros casos incluso se dan las abrogaciones o derogaciones, es decir, la totalidad o una parte del texto legal.

A veces también se dan a través de la inclusión o supresión de signos de puntuación, que como se sabe el sentido de los términos jurídicos, frases, oraciones o signos lingüísticos (significante), pueden variar debido a una supresión, inclusión o variación de los mismos.

Es necesario aclarar que el método gramatical o literal siempre será el punto de partida de cualquier propuesta de interpretación jurídico penal.

\section{Fórmulas indirectas o tácitas}

Se denominan indirectos o tácitos cuando no se mencionan precisiones gramaticales a través

del 2018, el cual fijo en su art. 1 el contenido vigente del art. 69 de la rehabilitación automática, con los alcances ante descritos. de los significantes jurídico-penales, dentro de un texto, en el cual donde la perspectiva del método gramatical o literal.

Por ejemplo, si dada una regla jurídica N1 que regula la modificación de las penas al incrementar sus montos. Sin embargo, si se concuerda con otra regla jurídica N2, en este caso la regla de la prescripción ordinaria, entonces sin ser modificada por el legislador sus supuestos se alterarían utilizándose el método sistemático de interpretación al concordarse N1 y N1, pues dicha concordancia producirá nuevas consecuencias jurídicas.

Es en el caso de todas aquellas iniciativas legislativas que, al modificar los supuestos típicos de un delito, así como los montos de la pena privativa de libertad y demás consecuencias jurídicas (N1), entonces necesariamente se modifican los plazos de prescripción de la acción penal y de la ejecución de la pena, sea ampliándolos o reduciéndolos, aunque los artículos que regulan la prescripción no se hayan modificado de ninguna manera (en nuestro ejemplo N2).

Es por esa razón que todas las iniciativas legislativas en materia de agresiones sexuales $\mathrm{y}$ otros tipos penales que proponían el incremento de la pena, también significaba el incremento de los plazos de prescripción de la acción penal y de la ejecución penal.

\section{ANÁLISIS DEL ARTÍCULO 88-A: LA IMPRESCRIPTIBILIDAD}

\section{Los fundamentos desde la perspectiva penal}

Lo más relevante de la reforma es que no está inspirada en la gravedad de los delitos o en la lesión de los bienes jurídicos desde una perspectiva material, sino más bien puramente formal.

Aunque, es curioso que en los fundamentos del dictamen sustitutorio desde la perspectiva constitucional se invocan los principios de igualdad y desigualdad, la integridad moral, la invocación de la disposición final de la Constitución de 1993, el bien jurídico y la relevancia constitucional, el test de proporcionalidad, el control de la proporcionalidad de penas, y la prohibición de la protección insuficiente. 
Por lo cual, si la idea era la protección de los menores de edad y adolescentes, hoy el Estado asumió una política penal de declarar imprescriptible todo tipo de delitos de agresión sexual, sea quien sea la víctima, así como sus afines teniendo un total de 32 artículos de la parte especial del Código Penal de 1991.

El caso de los menores de edad se justifica en atención al contenido del bien jurídico como lo señaló en su fundamento $\mathrm{N}^{\circ} 7 \mathrm{del}$ Acuerdo Plenario $\mathrm{N}^{\circ} 4 / 2008$ siguiendo a la doctrina italiana que suele distinguir entre el bien jurídico indemnidad e intangibilidad sexual:

Es de entender como libertad sexual la capacidad legalmente reconocida que tiene una persona para autodeterminarse en el ámbito de su sexualidad, y como indemnidad sexual la preservación de la sexualidad de una persona cuando no está en condiciones de decidir sobre su actividad sexual: menores e incapaces. En ambos casos es evidente que el fundamento material de las infracciones que las comprende es el derecho a una actividad sexual en libertad. Bajo estas premisas, corresponde establecer, desde la Constitución y las normas legales vigentes, desde qué edad una persona tiene libertad para disponer de su sexualidad $\mathrm{y}$, por consiguiente, hasta cuándo el Estado tiene el deber de criminalizar conductas asociadas a la vulneración de la indemnidad sexual. (Fundamento 7)

Es aquí donde se expresa una notable preocupación de las consecuencias futuras de la imprescriptibilidad penal de los delitos de agresión sexual, abuso sexual y delitos afines, pues ahora cualquier delito puede ser regulado como imprescriptible en el sistema penal peruano, ya que al estar desligado totalmente de la importancia del principio de lesión o puesta en peligro del bien jurídico y del principio de proporcionalidad, mañana más tarde cualquier delito se puede declarar imprescriptible, pues no se contará con criterios materiales para fundamentarlas, teniendo medidas populistas o de grupos de interés que no necesariamente signifique el interés general.

Así al comparar los criterios utilizados en la reforma penal constitucional a través de la inclusión de la imprescriptibilidad para los delitos de mayor gravedad contra la administración pública (art. 41 in fine de la Constitución), donde se consideraron dos criterios de distinción, primero el de aplicarla solo para los delitos de mayor gravedad, y el segundo que se afecte el patrimonio del Estado. Ello, como se ha evidenciado, no se aprecia en la imprescriptibilidad de los delitos de agresión sexual, abuso sexual y conexos, en donde dichos criterios no son los relevantes y solo se mencionan criterios de relevancia constitucional, pero desde una perspectiva puramente formal.

Otro aspecto que abona la justificación son los criterios de derecho penal internacional e ius cogens, al validar la imprescriptibilidad de determinados delitos regulados en el Estatuto Penal de Roma que ahora forman parte de nuestro derecho penal interno.

En síntesis, en el sistema penal peruano se tienen tres grupos de delitos que regulan la imprescriptibilidad, el primero los delitos regulados en el Estatuto Penal de Roma, el segundo, algunos delitos contra la administración pública, y el tercero, la reciente reforma penal que incluye a los delitos de agresión sexual y otros conexos.

\section{Los fundamentos de la Comisión de Justicia}

La Comisión establece precisando los siguientes fundamentos:

$\left.1^{\circ}\right) \mathrm{Se}$ invocan los Proyectos de Ley 1037/2016-CR, 1164/2016-CR, 1396/2016CR y 1602/2016-CR se propone la imprescriptibilidad de los delitos contra la libertad e indemnidad sexuales mediante la modificación del artículo 80 del Código Penal.

$2^{\circ}$ ) Se cita un fundamento de la resolución del TC que precisa la excepcionalidad de la supresión de la prescripción penal:

La prescripción, desde un punto de vista general, es la institución jurídica mediante la cual, por el transcurso del tiempo, la persona adquiere derechos o se libera de obligaciones. Y, desde la óptica penal, es una causa de extinción de la responsabilidad criminal fundada en la acción del tiempo sobre los acontecimientos humanos o la renuncia del Estado al ius punendi, en razón de que el tiempo transcurrido borra los efectos de 
la infracción, existiendo apenas memoria social de la misma. (Expediente $\mathrm{N}^{\circ} 1805$ 2005-PHC/TC, Fundamento 2)

En esa misma línea de ideas, el referido tribunal también ha expresado:

\section{La prescripción sólo debe ser sacrificada en situaciones excepcionales, por cuanto resulta inadmisible que la persecución de cualquier delito pueda ser efectuada sin límite alguno, haciendo a un lado el derecho a que el proceso penal sea tramitado dentro de un plazo razonable (Expediente $\mathrm{N}^{\circ}$ 00218-2009-PHC/TC, Fundamento 14)}

$3^{\circ}$ ) Otro de los supuestos es el de las graves dificultades para la persecución, por la omisión de denuncia por parte de las víctimas por razones diversas que van desde el temor, la vergüenza, hasta las amenazas de muerte directas a la víctima o sobre su familia.

$4^{\circ}$ ) Otro argumento es el hecho de solo mencionar los delitos materia de la imprescriptibilidad la Comisión aprueba que se declaren imprescriptibles tanto la pena como la acción penal de los delitos contra la libertad e indemnidad sexuales previstos en los capítulos IX, X, XI, del Título IV del Libro Segundo del Código Penal y de los delitos de explotación previstos en los artículos 153, 153A, 153-B y 153-C del citado código. La crítica es que por ninguna parte se justifica el hecho de haberse extendido a muchos delitos que no se han fundamentado para ser declarados imprescriptibles, aun cuando las penas no eran graves.

$\left.5^{\circ}\right)$ Se concluye tratando de justificar su ubicación desconociendo que el plazo de prescripción de la pena es el mismo que el de la acción penal, por lo cual la imprescriptibilidad debió ir en el art. 80 in fine para la acción penal y art. 86 in fine de la ejecución de la pena. Así se señala:

Finalmente, las propuestas coinciden en modificar el artículo 80 del Código Penal para incorporar la imprescriptibilidad de los referidos delitos. No obstante, la Comisión evidencia que el artículo $80 \mathrm{del}$ citado código se refiere a la prescripción de la acción penal, por lo que regular la imprescriptibilidad en un dispositivo legal que prevé una disposición contraria por técnica legislativa, no es apropiada. Por ello, la Comisión propone incorporar el artículo 88-A al Código Penal con la sumilla siguiente: Imprescriptibilidad de la pena y de la acción penal. (Comisión de Justicia y Derechos Humanos, 2017-2018, página 50).

\section{Reflexión final}

Como reflexión final, cabe analizar los alcances en torno a la imprescriptibilidad de la reciente reforma penal a través de la ley $\mathrm{N}^{\circ} 30838$, pues el hecho de establecer que en el catálogo de los delitos hoy considerados imprescriptibles se tienes 32 delitos, sin considerar sus modalidades ni agravantes, sin embargo, al evaluar cada uno de estos delitos, nos encontramos con supuestos de gravedad menores al homicidio, al lavado de activos, al terrorismo, al tráfico ilícito de drogas, entre otros delitos de mayor gravedad.

De allí que cabe preguntase: ¿si el homicidio cometido contra un menor de edad (niño o niña/ adolescente) en el contexto, por ejemplo, de un homicidio o feminicidio, desde la perspectiva de la prescripción, genera la irracional idea que la muerte de un menor realizado por un sujeto constituye un supuesto de prescriptible, frente a cualquier forma de agresión sexual, abuso sexual y/o delitos conexos, que ahora son considerados imprescriptible, empero, si el autor del delito dejara vivo al menor (niño o niña/ adolescente) que lo podría identificar, el autor optaría por matarlo, ya que los delitos de homicidio, feminicidio o sicariato son prescriptibles?

Finalmente, como ya se justificó arriba, los nuevos delitos de acoso (art. 151-A), difusión de imágenes, materiales, audiovisuales o audios con contenido sexual (art. 154-B), acoso sexual (art. 176-B) y el delito de chantaje sexual (art.176-C), constituye una excepción, pues son presupuestos prescriptibles. 


\section{LA PROBLEMÁTICA DEL ARTÍCULO 5 DE LA LEY N 30096, DELITO DE CIBER ACOSO INFANTIL O CHILD GROOMING ${ }^{14}$ LUEGO DE SU MODIFICACIÓN MEDIANTE LA LEY $\mathbf{N}^{\circ} 30838$.}

Una observación que hacemos a la reciente reforma desde la perspectiva de la imprescriptibilidad es que el legislador obvió incluir en los presupuestos del artículo 88-A lo dispuesto por el artículo 4 de la Ley No 30838 que señaló:

\section{CUADRO COMPARATIVO DE LOS ARTÍCULOS 183-B DEL CÓDIGO PENAL DE 1991 Y EL ART. 5 DE LA LEY No 30096}

"Artículo 183-B.- Proposiciones a niños, niñas y adolescentes con fines sexuales

El que contacta con un menor de catorce años para solicitar u obtener de él material pornográfico, o para proponerle llevar a cabo cualquier acto de connotación sexual con él o con tercero, será reprimido con pena privativa de libertad no menor de seis ni mayor de nueve años e inhabilitación conforme a los numerales 1, 2, 4 y 9 del artículo 36 .

Cuando la víctima tiene entre catorce y menos de dieciocho años, y medie engaño, la pena será no menor de tres ni mayor de seis años e inhabilitación conforme a los numerales 1, 2, 4 y 9 del artículo 36".
«Artículo 4. Modificación de la Ley 30096, Ley de Delitos Informáticos

Modifícase el artículo 5 de la Ley 30096, Ley de Delitos Informáticos, en los términos siguientes:

“Artículo 5.- Proposiciones a niños, niñas y adolescentes con fines sexuales por medios tecnológicos

El que a través de internet $\mathrm{u}$ otro medio análogo contacta con un menor de catorce años para solicitar u obtener de él material pornográfico o para proponerle llevar a cabo cualquier acto de connotación sexual con él o con tercero, será reprimido con una pena privativa de libertad no menor de cuatro ni mayor de ocho años e inhabilitación conforme a los numerales 1, 2, 4 y 9 del artículo 36 del Código Penal.

Cuando la víctima tiene entre catorce y menos de dieciocho años de edad y medie engaño, la pena será no menor de tres ni mayor de seis años e inhabilitación conforme a los numerales 1, 2, 4 y 9 del artículo 36 del Código Penal"».

Fuente: Elaboración propia

A partir de este texto se pueden formular las siguientes observaciones:

$1^{\circ}$. Ambos tipos penales regulados en el artículo 183-B del Código Penal y en el artículo 5 de la Ley penal especial $\mathrm{N}^{\circ} 30838$ tienen muchos elementos típicos en común, salvo algunos componentes del aspecto objetivo del art. 5 de la Ley $\mathrm{N}^{\circ} 30096^{15}$, como lo son: el medio empleado y el monto de la pena privativa de la libertad, que en el caso del art. 183-B del CP es no menor de seis ni mayor de nueve años.

$2^{\circ}$. De la diferencia del medio empleado, en el tipo penal del art. 5 de la Ley $\mathrm{N}^{\circ} 30096$ generalmente el sujeto activo suele utilizar el internet (email por ejemplo) o cualquier otro medio análogo (redes

14 Franco Gonzáles señala que "el child grooming se define como un comportamiento sexual ilícito que comprende una cadena ordenada de conductas, cuyo primer eslabón comienza cuando el agente- cualquier persona mayor de edad- siempre mediante el uso la TIC, procede a contactar con una menor de edad- a veces haciéndose pasar por otro menor-; luego cuidadosamente va desarrollando lazos emocionales con él va registrando datos personales de este, utilizando esa información lo va seduciendo y/o provocando; para finalmente llegar al último eslabón de la cadena, en el que se manifiesta el verdadero propósito que lo ha motivado: el solicitar u obtener del menor material pornográfico, o proponerle llevar a cabo actividades de connotación sexual con él” (Franco Gonzáles, C.A. (2015). "El delito de child gromming en la ley de delitos informáticos". Revista Actualidad Penal vol. 18, Lima, Perú; Instituto Pacífico, p. 256).

$15 \mathrm{Al}$ respecto es necesario remitir a Reyna Alfaro en torno a los alcances de lo que significa el delito informático y los distintos postulados (Reyna Alfaro, L. (2002). Los delitos informáticos. Aspectos criminológicos, dogmáticos y de política criminal. Lima, Perú: Jurista editores, p. 130 y ss.). 
sociales en general, whatsapp, bluetooth, NFC, entre otros) ${ }^{16}$, pues este medio permite estar virtualmente cerca, aunque sin estarlo físicamente, que es lo que generalmente el sujeto activo desea para actuar en sigilo o pasar inadvertido. Sin embargo, la pena privativa de libertad para esta modalidad resulta ser no menor de cuatro ni mayor de seis años.

$3^{\circ}$. En cambio, tratándose del artículo 183-B del Código Penal al establecerse la utilización de cualquier medio empleado, menos lo establecidos en el otro tipo penal regulado en el artículo 5 de la ley 30096, como lo puede ser una carta física o mensajes en físico $u$ otro análogo, que de por sí requieren de intermediarios o mensajeros, donde de por sí ya se pone en evidencia el sujeto activo, a través de la intervención de terceros o del mismo sujeto activo al acercarse a la víctima.

$4^{\circ}$. Todo indica que el legislador descuidó estos tipos penales al regular prácticamente lo mismo, pero con un tratamiento típico y sancionatorio contradictorio, pues a la modalidad más relevante hoy en día, le dio un tratamiento penal más benigno, mientras que a la modalidad menos utilizada le dio un tratamiento más relevante.

$5^{\circ}$. Finalmente, lo más observable de esta reforma realizada mediante la Ley $\mathrm{N}^{\circ} 30838$ es el caso de regular en su artículo 2 la imprescriptibilidad del delito de proposiciones a niños, niñas y adolescentes con fines sexuales (artículo 183-B del Código Penal).

Empero, el legislador olvidó o dejó de lado, el incluir al delito regulado en el artículo 4 de la Ley $\mathrm{N}^{\circ} 30838$, que dispuso la modificación del artículo 5 (sumillado como proposiciones a niños, niñas y adolescentes con fines sexuales por medios tecnológicos) de la ley especial de los delitos informáticos $\mathrm{N}^{\circ} 30096$, dentro de los alcances de la imprescriptibilidad.

$16 \mathrm{Al}$ respecto es interesante lo señalado por el profesor Jiménez Herrera al señalar que "La intención del legislador es proteger, nuevamente, estos bienes jurídicos convencionales, pero, en este caso cuando el agente haya utilizado como medio para la comisión del delito, algún medio tecnológico, tales como el ordenador. En consecuencia, el legislador nacional ha tipificado idéntica conducta ilícita en dos tipos penales distintos- la primera en el Código penal y la segunda en una ley especial-, el criterio para dividir una conducta de las otras es el mecanismo o medio utilizado por el agente para cometer el ilícito. En efecto, si esteel agente- utiliza los medios convencionales como la carta, telegrama, una conversación directa o indirecta, se le aplicara el Código penal. Sin embargo, si para la realización de su comisión, hace uso del Messenger, correo electrónico, Facebook, twiter, web, etc., se le aplicará una ley especial: la LDI (Ley de los Delitos Informáticos)" (Jiménez Herrera, J.C. (2017). Manual de Derecho Penal Informático, Lima, Perú, Editorial Jurista E.I.R.L., p. 423)
La consecuencia de este olvido, omisión o error, que es urgente corregir, es que para efectos de la prescripción el imputado invocará los alcances del artículo 5 de la Ley $\mathrm{N}^{\circ} 30096$, que no solo le tiene menos pena privativa de la libertad, sino que es prescriptible, pues su monto de prescripción ordinaria, tanto de la acción penal como de la ejecución de la pena, es de 8 años, y para el caso de la prescripción extraordinaria es de 12 años. La corrección de este olvido, omisión o error se tendrá que dar incorporando este supuesto en los alcances del artículo 88-A del Código Penal.

Al no hacerse la corrección prácticamente los alcances del artículo 183-B del Código Penal será de un tipo penal imprescriptible, pero inaplicable.

\section{CONCURSO DE DELITOS E IMPRESCRIPTIBILIDAD}

Otro aspecto, a preguntarse es: ¿si la imprescriptibilidad de los delitos de agresión sexual y conexos (excluyendo el art. 173 del Código Penal) que concurren o concursan con otros delitos de mayor gravedad punitiva, neutralizan el concurso?

Como se aprecia en el art. 80 del Código Penal de 1991, se establecieron las reglas para los concursos y la prescripción, sin embargo, aun cuando las reglas del concurso real e ideal se modificaron sus consecuencias, en el caso de la prescripción ello no aconteció, de allí que, si hay concurso real o ideal, se aplica la consecuencia jurídica del art. 80 párrafo segundo (concurso real) o párrafo tercero (concurso ideal), dependiendo del caso concreto.

En el caso del concurso real no habrá problemas, pues cada delito prescribe individualmente. Empero, en el concurso ideal sí, pues la consecuencia jurídica es: "Las acciones prescriben cuando haya transcurrido un plazo igual al máximo correspondiente al delito más grave". Pero, la pena más grave no es la del delito de agresión sexual y conexos, si excluimos al 173 del Código Penal, así por ejemplo cuando nos referimos a los delitos de tocamientos, favorecimiento de la prostitución, proxenetismo, rufianismo, pornografía infantil entre otros, con el homicidio, el feminicidio, el sicariato, entre otros. 
De todo esto se desprende que la regla del concurso al interpretarse la regla del art. 88-A de la imprescriptibilidad o como prohibición de la prescripción, hacen inviable la posibilidad del concurso ideal, pues si bien el delito de homicidio es más grave que el rufianismo, empero el rufianismo es imprescriptible por ende la regla de delito más grave no opera, al tener ahora un modelo de imprescriptibilidad que no se basa en el delito más grave, sino en una consideración puramente de política penal, creo que lo viable es que se siga discutiendo el tema.

De allí que el mejor homenaje para proteger a nuestros menores de edad, niños y adolescentes, requiere de hacer algo trascendente y relevante en atención al próximo bicentenario de fundación de la República, lo lógico es que se formule una política de estado en todos los flancos, no solo en Código Penal y en el Código del Niño y Adolescente, o en la Constitución como han realizado otros países (Ecuador y Bolivia), sino en el plano educativo, deportivo, cultural, salud física y mental, con la correspondiente planificación, solo de esta manera los penalistas no nos dedicaremos a realizar interpretaciones en salvaguarda de intentos, experimentos o parcialidades populistas y no a reformas trascendentales que viabilicen un futuro viable para nuestro país.

\section{CONCLUSIONES}

La reciente incorporación al Código Penal de 1991 de la imprescriptibilidad de la acción o persecución penal, así como de la ejecución de la pena para los delitos de agresión sexual, abuso sexual y otros delitos conexos, ha tenido como fundamento la reiterada agresión y abuso a víctimas vulnerables como niños $\mathrm{y}$ niñas principalmente y al derecho comparado, dejándose de lado las otras opciones como lo fueron, en primer lugar la ampliación del plazo de prescripción a través del incremento de la pena privativa de la libertad conminada (la tradición peruana) y en segundo lugar la suspensión del plazo de prescripción hasta que la víctima alcance la mayoría de edad (la mayoría de países sudamericanos y caribeños, así como España).

La imprescriptibilidad de los delitos de agresión sexual, abuso sexual y delitos conexos está condicionado por la selección de un grupo de delitos regulados en el art. 88-A del Código Penal, al margen de la calidad de las víctimas, pues ahora ya no importará si la víctima es un niño o una niña, un adolescente, un adulto o adulto mayor, etc., ya que la figura de la imprescriptibilidad se ha construido sobre la base del delito, siguiendo el modelo español y abandonando la tradición peruana más bien dependiente de los tipos de pena, cualquiera sea su modalidad comisiva de resultado material o de peligro, delitos de mera actividad, de actos preparatorios punibles, entre otros, y que ya se había manifestado en la reforma constitucional de la imprescriptibilidad para los delitos de corrupción en el Perú.

La regulación de la imprescriptibilidad para las infracciones penales de agresiones sexuales, abusos sexuales y delitos conexos ha utilizado el argumento de las víctimas vulnerables menores de edad (niño o niña adolescente), empero su aplicación es para todo tipo de víctimas, aspecto que no se fundamentó en ninguno de los proyectos de ley ni en la exposición de motivos de la Ley $\mathrm{N}^{\circ} 30838$, art. 2, que incorporó el art. 88-A al Código Penal al regular legislativamente la imprescriptibilidad penal.

\section{FUENTES DE INFORMACIÓN}

\section{Fuentes bibliográficas}

Cornejo, G. y Jiménez, P. (1927). Código penal. Primer anteproyecto de la comisión parlamentaria nombrada conforme a la ley $N^{\circ}$ 5168, Lima, Perú: Imprenta Minerva.

Cerrada Moreno, Manuel (2018). Prescripción e imprescriptibilidad de los delitos. Orígenes. Fundamentos. Naturaleza jurídica. Barcelona, España: Bosch Editor.

Galindo, A. y Ujaldón, E. (Dir.) (2018). ¿Quién dijo populismo?. Madrid, España: Biblioteca Nueva con el sello de Minerva.

García-Escudero Márquez, P. (2011). Manual de técnica legislativa. Madrid, España: Aranzadi.

Jiménez Herrera, J.C. (2017). Manual de Derecho Penal Informático, Lima, Perú: Editorial Jurista E.I.R.L.

Reyna Alfaro, L.M. (2002). Los delitos informáticos. Aspectos criminológicos, dogmáticos y de política criminal. Lima, Perú: Jurista Editores. 
Roy Freyre, L. E. (2018). Causas de extinción de la acción penal y de la pena. Lima, Perú: Gaceta Jurídica.

Salinas Siccha, R. (2016). Los delitos contra la libertad e indemnidad sexual. Doctrina $y$ jurisprudencia, ( $3^{\mathrm{a}}$ ed.). Lima, Perú: Instituto Pacífico.

Vidaurre, M.L. (1928). Proyecto de un código penal. Impresa en Boston por Hiram Tupper.

\section{Fuentes hemerográficas}

Franco Gonzáles, C.A. (2015). "El delito de child grooming en la ley de delitos informáticos. Análisis y deficiencias en su técnica legislativa". Revista Actualidad Penal, 18, páginas 250-265.

\section{Fuentes electrónicas}

Alarcón Hermosa, Elena (2017). Informe Temático $\mathrm{N}^{\circ}$ 13/2017-2018. Recuperado del sitio de internet: http:// www2.congreso.gob.pe/sicr/cendocbib/con5_uibd. nsf/75C210AA031030F1052581C600789CC2/\$FILE/ InformeTem\%C3\%A1tico-ImprescriptibilidadFINAL. pdf

Berrios, M. (2018). “En dos años saldrán en libertad 717 presos por agresión sexual". Publicado en el diario La República. Recuperado del sitio de internet: https://larepublica.pe/sociedad/1297057anos-saldran-libertad-717-presos-agresion-sexual

Weidenslaufer, Christine(2016). "Imprescriptibilidad de acciones civiles y /o penales por delitos sexuales contra menores de edad en el derecho comparado". Recuperado del sitio de internet: https://www.ben. cl/obtienearchivo?id=repositorio/10221/23428/2/ imprescriptibilidad $\% 20 \mathrm{de} \% 20$ abuso $\% 20$ sexual\%202016_eval.pdf

Hamilton, J., Jackson, V., Mora, J. (2018). Derecho al tiempo. Fundamentos y Propuestas para la Imprescriptibilidad de la Acción Penal respecto a delitos de agresión sexual contra niños, niñas y adolescentes, 12 de abril de 2018. Recuperado del sitio de internet https://abusosexualimprescriptible. cl/wp-content/uploads/2018/04/Propuesta_ASI Imprescriptible_-_Abril-2018_con-resumen_2.pdf
Congreso de la República del Perú (2018). Dictamen de la Comisión de Justicia y Derechos Humanos recaídos en los proyectos de ley 460/2016-CR, 1037/2016-CR, 1069/2016-CR, 1164/2016-CR, 1396/2016-CR, 1602/2016-CR, 1989/2017-CR, 2013/2017-CR, 2070/2017-CR, 2119/2017-CR, 2165/2017-CR, 2174/2017-CR, 2258/2017-CR, 2305/2017-CR, 2316/2017-CR, 2402/2017-CR, 2415/2017-CR, 2416/2017-CR, 2460/2017-CR, 2485/2017CR y 2536/2017-CR. Recuperado del sitio de internet: http://www.leyes.congreso.gob.pe/ Documentos/2016_2021/Texto_Sustitutorio/ Proyectos_de_Ley/T̄S0046020180517.pdf

Fernández Calvo, L. (2018). "El silencioso abuso a la niñez". Publicado en el diario El Comercio, lunes 13 de agosto del 2018. Recuperado del sitio de internet: https://elcomercio.pe/peru/violacionmenores-hay-ocho-mil-presos-peru-delitonoticia-546166

Sáenz Torres, Alexei Dante (2018). La prohibición de la prescripción o la imprescriptibilidad como reforma penal inconstitucional. Revista Vox Juris. 36 (2), página 147-161, Disponible enhttps:// www.aulavirtualusmp.pe/ojs/index.php/VJ/article/ viewFile/1312/pdf12

Sáenz Torres, Alexei Dante (2012). La prescripción penal en el Perú (a veinte años de vigência del Código Penal de 1991). Recuperada del sitio de internet http://cybertesis.unmsm.edu. pe/bitstream/handle/cybertesis/7980/Saenz ta.pdf? sequence $=1$ \&isAllowed $=\mathrm{y}$

\section{Jurisprudencia}

Tribunal Constitucional (2010). STC: Expediente No. 00218-2009-PHC/TC. Caso Roberto Contreras. Sentencia de $11 \mathrm{de}$ noviembre de 2010.

Tribunal Constitucional (2010). STC: Expediente No. 00218-2009-PHC/TC. Caso Roberto Contreras. Sentencia de 11 de noviembre de 2010. Fundamento jurídico 14, voto singular del magistrado Álvarez Miranda. Tribunal Constitucional del Perú. 
ANEXO

\begin{tabular}{|c|c|c|c|c|c|}
\hline \multicolumn{6}{|c|}{$\begin{array}{l}\text { 9. ANEXO ÚNICO: PROYECTOS DE LEY QUE JUSTIFICARON LA INTRODUCCIÓN DE LA } \\
\text { IMPRESCRIPTIBILIDAD PARA EL DELITO DE AGRESIONES SEXUALES Y CONEXOS }\end{array}$} \\
\hline N. & $\begin{array}{l}\text { PROYECTO } \\
\text { DE LEY }\end{array}$ & FЕСНА & CONGRESISTA & TÍTULO & REFORMA \\
\hline 1 & 1063/2011-CR & 03/05/2012 & $\begin{array}{l}\text { Marco Tulio } \\
\text { Falconi Picardo } \\
\text { Grupo } \\
\text { Parlamentario } \\
\text { Alianza } \\
\text { Parlamentaria }\end{array}$ & $\begin{array}{l}\text { Ley que modifica el } \\
\text { art. } 80^{\circ} \text { del código } \\
\text { penal y "declara la } \\
\text { imprescriptibilidad de los } \\
\text { delitos de violación sexual } \\
\text { contra menores de edad" }\end{array}$ & $\begin{array}{l}\text { ARTICULO PRIMERO } \\
\text { Modifíquese el artículo } 80^{\circ} \text { del Código } \\
\text { Penal, debiendo quedar redactado de la forma } \\
\text { siguiente: } \\
\text { Artículo 80.- Prescripción de la acción penal- } \\
\text { Plazos } \\
\text { La acción penal prescribe en un tiempo igual } \\
\text { al máximo de la pena fijada por la ley para el } \\
\text { delito, si es privativa de libertad } \\
\text { En caso de concurso real de delitos, las } \\
\text { acciones prescriben separadamente en el plazo } \\
\text { señalado apra cada uno. } \\
\text { En caso de concurso ideal de delitos, las } \\
\text { acciones prescriben cuando haya transcurrido } \\
\text { un plazo igual al máximo correspondiente al } \\
\text { delito más grave. } \\
\text { La prescripción no será mayor a veinte años. } \\
\text { Tratándose de delitos sancionados con pena de } \\
\text { cadena perpetua se extingue la acción penal a } \\
\text { los treinta años. } \\
\text { En los delitos que merezcan otras penas, la } \\
\text { acción prescribe a los dos años. } \\
\text { En caso de delitos cometidos por funcionarios } \\
\text { y servidores públicos contra el patrimonio del } \\
\text { Estado o de organismos sostenidos por éste, el } \\
\text { plazo de prescripción se duplica. } \\
\text { La acción penal es imprescriptible } \\
\text { tratándose de delitos contra la libertad, en } \\
\text { su modalidad de delitos de violación de la } \\
\text { libertad sexual de menor de edad regulado } \\
\text { en el artículo 173 y violación sexual de } \\
\text { menor de edad seguida de muerte o lesión } \\
\text { grave regulado en el artículo 173-A, del } \\
\text { presente Código". } \\
\text { ARTíCULO SEGUNDO.- } \\
\text { La presente ley tiene vigencia desde el día } \\
\text { siguiente de su publicación en el Diario Oficial. }\end{array}$ \\
\hline 2 & 4954/2015-CR & $05 / 11 / 2015$ & $\begin{array}{l}\text { Carlos Bruce } \\
\text { Montes de Oca }\end{array}$ & $\begin{array}{l}\text { Proyecto de ley que } \\
\text { declara imprescriptibles } \\
\text { los delitos por abusos } \\
\text { sexuales contra menores } \\
\text { de edad }\end{array}$ & $\begin{array}{l}\text { FÓRMULA LEGAL } \\
\text { "Artículo Único.- Modificación del Artículo } \\
\mathbf{8 0}^{\circ} \text { del Código Penal } \\
\text { Modifíquese el artículo } 80^{\circ} \text { del Código Penal, } \\
\text { agregándose al final del mismo el texto } \\
\text { siguiente: } \\
\text { "Artículo } 80^{\circ} \text {.- Plazos de la prescripción de la } \\
\text { acción penal } \\
\text { (...). } \\
\text { En el caso de los delitos incurridos contra } \\
\text { la libertad sexual de menores de } 14 \text { años, la } \\
\text { acción penal será imprescriptible"”. }\end{array}$ \\
\hline
\end{tabular}


e indemnidad sexual en el perú

The imprescriptibility of crimes against freedom

and sexual indemnity in peru

\begin{tabular}{|c|c|c|c|c|c|}
\hline \multicolumn{6}{|c|}{$\begin{array}{l}\text { 9. ANEXO ÚNICO: PROYECTOS DE LEY QUE JUSTIFICARON LA INTRODUCCIÓN DE LA } \\
\text { IMPRESCRIPTIBILIDAD PARA EL DELITO DE AGRESIONES SEXUALES Y CONEXOS }\end{array}$} \\
\hline N. & $\begin{array}{l}\text { PROYECTO } \\
\text { DE LEY }\end{array}$ & FЕСНА & CONGRESISTA & TÍTULO & REFORMA \\
\hline 3 & 1022/2016-CR & $07 / 03 / 2017$ & $\begin{array}{l}\text { Liliana Milagros } \\
\text { Takayama } \\
\text { Jiménez, } \\
\text { Alejandra } \\
\text { Aramayo Goana, } \\
\text { Milagros Salazar } \\
\text { de la Torre. } \\
\text { Grupo } \\
\text { Parlamentario } \\
\text { Fuerza Popular }\end{array}$ & $\begin{array}{l}\text { Ley que reforma el código } \\
\text { penal para sancionar } \\
\text { la violación sexual } \\
\text { sistemática de menores } \\
\text { como crimen de lesa } \\
\text { humanidad y establecer su } \\
\text { imprescriptibilidad }\end{array}$ & $\begin{array}{l}\text { "Artículo 80.- Plazos de prescripción de la } \\
\text { acción penal” } \\
\text { (...) } \\
\text { Cuando la violación sexual de menores de } \\
\text { edad es cometida como un crimen de lesa } \\
\text { humanidad aprovechando una relación de } \\
\text { autoridad, la acción penal es imprescriptible. } \\
\text { En ese supuesto también está prohibido } \\
\text { el otorgamiento de amnistía, de indulto y } \\
\text { beneficios penitenciarios dirigidos a acortar la } \\
\text { pena privativa de libertad." } \\
\text { "Artículo 170-A. Violación sexual de menores } \\
\text { como crimen de lesa humanidad. } \\
\text { El que mediante amenaza o violencia, fisica } \\
\text { o psicológica, o aprovechando un entorno } \\
\text { de coacción o una relación de autoridad o } \\
\text { influencia en menores de edad, o de cualquier } \\
\text { otra forma similar, tiene acceso carnal por vía } \\
\text { vaginal, anal o bucal o realiza cualquier otro } \\
\text { acto análogo con la introducción de cualquier } \\
\text { objeto o parte del cuerpo por alguna de las dos } \\
\text { primeras vías, es reprimido con pena privativa } \\
\text { de libertad no menor de treinta años". }\end{array}$ \\
\hline 4 & 1037/2016-CR & 08/03/2017 & $\begin{array}{l}\text { Luciana Milagros } \\
\text { León Romero } \\
\text { Célula } \\
\text { Parlamentaria } \\
\text { Aprista }\end{array}$ & $\begin{array}{l}\text { Ley que declara la } \\
\text { imprescriptibilidad de } \\
\text { los delitos de violación } \\
\text { de la libertad sexual e } \\
\text { incrementa sus penas }\end{array}$ & $\begin{array}{l}\text { “Artículo 80.- Plazos de prescripción de la } \\
\text { acción penal” } \\
\text { La acción penal prescribe en un tiempo igual } \\
\text { al máximo de la pena fijada por la ley para el } \\
\text { delito, si es privativa de libertad. } \\
\text { En caso de concurso real de delitos, las } \\
\text { acciones prescriben separadamente en el plazo } \\
\text { señalado para cada uno. } \\
\text { En caso de concurso ideal de delitos, las } \\
\text { acciones prescriben cuando haya transcurrido } \\
\text { un plazo máximo correspondiente al delito más } \\
\text { grave. } \\
\text { La prescripción no será mayor a veinte años. } \\
\text { Tratándose de delitos sancionados con pena de } \\
\text { cadena perpetua se extingue la acción penal a } \\
\text { los treinta años. } \\
\text { En casos de delitos cometidos por funcionarios } \\
\text { y servidores públicos contra el patrimonio del } \\
\text { Estado o de organismos sostenidos por este, o } \\
\text { cometidos como integrante de organizaciones } \\
\text { criminales, el plazo de prescripción se duplica. } \\
\text { La acción penal es imprescriptible tratándose } \\
\text { de los delitos de violación de la libertad sexual } \\
\text { regulados en los artículos 170, 171, 172, 173- } \\
\text { A. 173-B, 174 y 176, así como las formas } \\
\text { agravadas a que se refiere el artículo 177 del } \\
\text { presente Código”. }\end{array}$ \\
\hline
\end{tabular}




\begin{tabular}{|c|c|c|c|c|c|}
\hline \multicolumn{6}{|c|}{$\begin{array}{l}\text { 9. ANEXO ÚNICO: PROYECTOS DE LEY QUE JUSTIFICARON LA INTRODUCCIÓN DE LA } \\
\text { IMPRESCRIPTIBILIDAD PARA EL DELITO DE AGRESIONES SEXUALES Y CONEXOS }\end{array}$} \\
\hline N. & $\begin{array}{l}\text { PROYECTO } \\
\text { DE LEY }\end{array}$ & FECHA & CONGRESISTA & TÍTULO & REFORMA \\
\hline 5 & 1046/2016-CR & 09/03/2017 & $\begin{array}{c}\text { Maritza Matilde } \\
\text { García Jiménez } \\
\text { Grupo } \\
\text { Parlamentario } \\
\text { "Fuerza } \\
\text { Popular". }\end{array}$ & $\begin{array}{l}\text { Proyecto de ley que } \\
\text { modifica el artículo } \\
377^{\circ} \text { del Código Penal y } \\
\text { sanciona al funcionario } \\
\text { que por omisión o retardo } \\
\text { favorece la prescripción } \\
\text { de actos funcionales en } \\
\text { agravio del Estado. }\end{array}$ & $\begin{array}{l}\text { "Artículo 377. Omisión, Rehusamiento o } \\
\text { demora de actos funcionales. } \\
\text { El funcionario o servidor público que, } \\
\text { ilegalmente, omite, rehúsa o retarda algún acto } \\
\text { de su cargo será reprimido con pena privativa } \\
\text { de libertad no mayor de dos años y con treinta } \\
\text { a sesenta días-multa. } \\
\text { Cuando la omisión, rehusamiento o demora de } \\
\text { actas funcionales esté referido a una solicitud } \\
\text { de garantías personales, o caso de violencia } \\
\text { familiar, la pena será privativa de libertad no } \\
\text { menor de dos ni mayor de cinco años" } \\
\text { Si la omisión, rehusamiento o retardo de } \\
\text { actos funcionales inherente a su labor o } \\
\text { función, causa la prescripción del proceso, } \\
\text { será reprimido con pena de libertad no } \\
\text { menor de dos ni mayor de cinco años y con } \\
\text { la inhabilitación prevista en el artículo } 36.1 \\
\text { del Código Penal”. }\end{array}$ \\
\hline 6 & 1069/2016-CR & $14 / 03 / 2017$ & 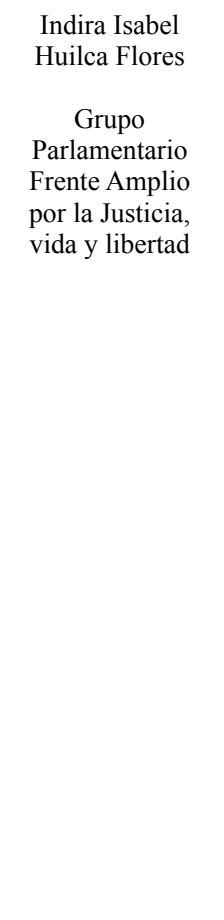 & $\begin{array}{l}\text { Imprescriptibilidad de los } \\
\text { delitos contra la libertad } \\
\text { e integridad sexual en } \\
\text { víctimas menores de } 18 \\
\text { años }\end{array}$ & $\begin{array}{l}\text { "Artículo 1. Modificación del artículo } 80 \text { del } \\
\text { Código Penal } \\
\text { Modifíquese el artículo } 80^{\circ} \text { del Código Penal, } \\
\text { en los siguientes términos: } \\
\text { Artículo } 80^{\circ} \text { del Código Penal.- Plazos de } \\
\text { prescripción } \\
\text { La acción penal prescribe en un tiempo igual } \\
\text { al máximo de la pena fijada por la ley para el } \\
\text { delito, si es privativa de libertad. } \\
\text { En caso de concurso real de delitos, las } \\
\text { acciones prescriben separadamente en el plazo } \\
\text { señalado para cada uno. } \\
\text { En caso de concurso ideal de delitos, las } \\
\text { acciones prescriben cuando haya transcurrido } \\
\text { un plazo igual al máximo correspondiente al } \\
\text { delito más grave. } \\
\text { La prescripción no será mayor a veinte años. } \\
\text { Tratándose de delitos sancionados con pena de } \\
\text { cadena perpetua se extingue la acción penal a } \\
\text { los treinta años. } \\
\text { En los delitos cometidos por funcionarios y } \\
\text { servidores públicos contra el patrimonio del } \\
\text { Estado o de organismos sostenidos por éste, el } \\
\text { plazo de prescripción se duplica. } \\
\text { Tratándose de los delitos comprendidos en } \\
\text { los capítulos IX y X del Título IV, Libro } \\
\text { Segundo del Código Penal, cometidos en } \\
\text { agravio de personas menores de } \mathbf{1 8} \text { años, la } \\
\text { acción penal es imprescriptible". }\end{array}$ \\
\hline
\end{tabular}


e indemnidad sexual en el perú

The imprescriptibility of crimes against freedom

and sexual indemnity in peru

\begin{tabular}{|c|c|c|c|c|c|}
\hline \multicolumn{6}{|c|}{$\begin{array}{l}\text { 9. ANEXO ÚNICO: PROYECTOS DE LEY QUE JUSTIFICARON LA INTRODUCCIÓN DE LA } \\
\text { IMPRESCRIPTIBILIDAD PARA EL DELITO DE AGRESIONES SEXUALES Y CONEXOS }\end{array}$} \\
\hline N. & $\begin{array}{l}\text { PROYECTO } \\
\text { DE LEY }\end{array}$ & FЕСНА & CONGRESISTA & TÍTULO & REFORMA \\
\hline 7 & 1164/2016-CR & $05 / 04 / 2017$ & $\begin{array}{l}\text { Miguel Román } \\
\text { Valdivia }\end{array}$ & $\begin{array}{l}\text { Ley que declara la } \\
\text { imprescriptibilidad de los } \\
\text { delitos de homicidio y de } \\
\text { violación de la libertad } \\
\text { sexual }\end{array}$ & $\begin{array}{l}\text { “Artículo 80.-Plazos de prescripción de la } \\
\text { acción penal } \\
\text { La acción penal prescribe en un tiempo igual } \\
\text { al máximo de la pena fijada por la ley para el } \\
\text { delito, si es privativa de libertad. } \\
\text { En caso de concurso real de delitos, las } \\
\text { acciones prescriben separadamente en el plazo } \\
\text { señalado para cada uno. } \\
\text { En caso de concurso ideal de delitos, las } \\
\text { acciones prescriben cuando haya transcurrido } \\
\text { un plazo igual al máximo correspondiente al } \\
\text { delito más grave. } \\
\text { La prescripción no será mayor a veinte años. } \\
\text { Tratándose de delitos sancionados, con pena de } \\
\text { cadena perpetua se extingue la acción penal a } \\
\text { los treinta años. } \\
\text { En los delitos que merezcan otras penas, la } \\
\text { acción prescribe a los dos años. } \\
\text { En casos de delitos cometidos por funcionarios } \\
\text { y servidores públicos contra el patrimonio del } \\
\text { Estado o de organismos sostenidos por este, o } \\
\text { cometidos como integrante de organizaciones } \\
\text { criminales, el plazo de prescripción se duplica. } \\
\text { Es imprescriptible la acción penal de los } \\
\text { delitos de homicidio regulados en los artículos } \\
106 \text { al } 113 \text { del presente Código; así como } \\
\text { los delitos de violación de la libertad sexual } \\
\text { contemplados en los artículos 170 al } 178 \text { del } \\
\text { mismo cuando legal”. }\end{array}$ \\
\hline 8 & 1396/2016-CR & $16 / 05 / 2017$ & $\begin{array}{l}\text { Alejandra } \\
\text { Aramayo } \\
\text { Goana, Úrsula } \\
\text { Letona Pereyra, } \\
\text { Milagros Salazar } \\
\text { de la Torre, } \\
\text { Liliana Milagros } \\
\text { Takayama } \\
\text { Jiménez } \\
\text { Grupo } \\
\text { Parlamentario } \\
\text { Fuerza Popular. }\end{array}$ & $\begin{array}{l}\text { Proyecto de ley que } \\
\text { incorpora al código penal } \\
\text { el delito de violación } \\
\text { sexual sistemática } \\
\text { de menores de edad } \\
\text { como crimen de lesa } \\
\text { humanidad y establece su } \\
\text { imprescriptibilidad }\end{array}$ & $\begin{array}{l}\text { “Artículo 80.- Plazos de prescripción de la } \\
\text { acción penal } \\
\text { (...) } \\
\text { En casos del delito de violación sexual } \\
\text { sistemática de menores de edad por constituir } \\
\text { un crimen de lesa humanidad, la acción penal } \\
\text { es imprescriptible. }\end{array}$ \\
\hline
\end{tabular}




\section{ANEXO ÚNICO: PROYECTOS DE LEY QUE JUSTIFICARON LA INTRODUCCIÓN DE LA} IMPRESCRIPTIBILIDAD PARA EL DELITO DE AGRESIONES SEXUALES Y CONEXOS

\begin{tabular}{|c|c|c|c|c|c|}
\hline N. & $\begin{array}{c}\text { PROYECTO } \\
\text { DE LEY }\end{array}$ & FЕСНА & CONGRESISTA & TÍTULO & REFORMA \\
\hline 9 & 1602/2016-CR & $28 / 06 / 2017$ & $\begin{array}{l}\text { Moisés Bartolomé } \\
\text { Guia Pianto y } \\
\text { otros }\end{array}$ & $\begin{array}{l}\text { Proyecto de ley } \\
\text { que establece la } \\
\text { imprescriptibilidad de los } \\
\text { delitos contra la libertad } \\
\text { sexual y la muerte civil de } \\
\text { los violadores }\end{array}$ & $\begin{array}{l}\text { “(...). } \\
\text { Artículo 2.- Modificación del artículo } 80^{\circ} \text { del } \\
\text { Código Penal, sobre la imprescriptibilidad de } \\
\text { los delitos de violación a la libertad sexual } \\
\text { Modifíquese el artículo } 80^{\circ} \text { del Código Penal } \\
\text { en los siguientes términos: } \\
\text { "Artículo } 80 .- \text { Plazos de prescripción de la } \\
\text { acción penal } \\
\text { La acción penal prescribe en un tiempo igual } \\
\text { al máximo de la pena fijada por la ley para el } \\
\text { delito, si es privativa de libertad. } \\
\text { En caso de concurso ideal de delitos, las } \\
\text { acciones prescriben separadamente en el plazo } \\
\text { señalado para cada uno. } \\
\text { En caso de concurso ideal de delitos, las } \\
\text { acciones prescriben cuando haya transcurrido } \\
\text { un plazo igual al máximo correspondiente al } \\
\text { delito más grave. } \\
\text { La prescripción no será mayor a veinte años. } \\
\text { Tratándose de delitos sancionados con pena de } \\
\text { cadena perpetua se extingue la acción penal a } \\
\text { los treinta años. } \\
\text { En los delitos que merezcan otras penas, la } \\
\text { acción prescribe a los dos años. } \\
\text { En casos de delitos cometidos por funcionarios } \\
\text { y servidores públicos contra el patrimonio del } \\
\text { Estado o de organismos sostenidos por éste, el } \\
\text { plazo de prescripción se duplica. } \\
\text { En los casos de delitos de violación de la } \\
\text { libertad sexual incluidos en } \text { el CAPÍTULO } \\
\text { IX, la acción penal es imprescriptible””. }\end{array}$ \\
\hline
\end{tabular}


e indemnidad sexual en el perú

The imprescriptibility of crimes against freedom

and sexual indemnity in peru

\begin{tabular}{|c|c|c|c|c|c|}
\hline \multicolumn{6}{|c|}{$\begin{array}{l}\text { 9. ANEXO ÚNICO: PROYECTOS DE LEY QUE JUSTIFICARON LA INTRODUCCIÓN DE LA } \\
\text { IMPRESCRIPTIBILIDAD PARA EL DELITO DE AGRESIONES SEXUALES Y CONEXOS }\end{array}$} \\
\hline N. & $\begin{array}{l}\text { PROYECTO } \\
\text { DE LEY }\end{array}$ & FЕСНА & CONGRESISTA & TÍTULO & REFORMA \\
\hline 10 & 1989/2017-CR & $10 / 10 / 2017$ & $\begin{array}{l}\text { Alberto de } \\
\text { Belaunde } \\
\text { Grupo } \\
\text { Parlamentario } \\
\text { Peruanos Por el } \\
\text { Kambio }\end{array}$ & $\begin{array}{l}\text { Ley que modifica el } \\
\text { artículo } 82 \text { del código } \\
\text { penal y establece un nuevo } \\
\text { inicio para el cómputo } \\
\text { de la prescripción de la } \\
\text { acción penal en los delitos } \\
\text { contra la indemnidad y } \\
\text { libertad sexual de niñas, } \\
\text { niños y adolescentes }\end{array}$ & 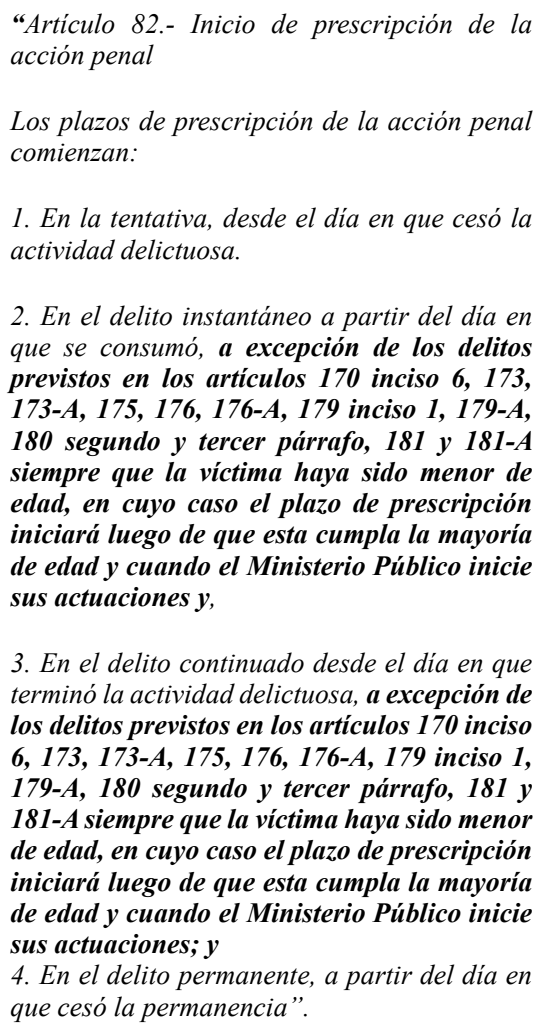 \\
\hline 11 & 2013/2017-CR & $17 / 10 / 2017$ & $\begin{array}{l}\text { Cecilia Chacón } \\
\text { De Vettori } \\
\text { Grupo } \\
\text { Parlamentario } \\
\text { Fuerza Popular }\end{array}$ & $\begin{array}{l}\text { Ley que modifica el } \\
\text { artículo } 82^{\circ} \text { del código } \\
\text { penal }\end{array}$ & $\begin{array}{l}\text { "Artículo 82.- Los plazos de prescripción de } \\
\text { la acción penal comienzan: } \\
\text { 1. En la Tentativa, desde el día en que cesó la } \\
\text { actividad delictuosa; } \\
\text { 2. El delito instantáneo, a partir del día en que } \\
\text { se consumó; } \\
\text { En el delito continuado, desde el día en que } \\
\text { terminó la actividad delictuosa; y } \\
\text { 3. En el delito continuado, desde el día en que } \\
\text { terminó la actividad delictuosa; y } \\
\text { 4. En el delito permanente, a partir del día en } \\
\text { que cesó la permanencia. } \\
\text { 5. En el delito violación sexual de menor } \\
\text { de edad, a partir del día en que cumple la } \\
\text { mayoría de edad". }\end{array}$ \\
\hline
\end{tabular}




\begin{tabular}{|c|c|c|c|c|c|}
\hline \multicolumn{6}{|c|}{$\begin{array}{l}\text { 9. ANEXO ÚNICO: PROYECTOS DE LEY QUE JUSTIFICARON LA INTRODUCCIÓN DE LA } \\
\text { IMPRESCRIPTIBILIDAD PARA EL DELITO DE AGRESIONES SEXUALES Y CONEXOS }\end{array}$} \\
\hline N. & $\begin{array}{l}\text { PROYECTO } \\
\text { DE LEY }\end{array}$ & FECHA & CONGRESISTA & TÍTULO & REFORMA \\
\hline 12 & 2070/2017-CR & $02 / 11 / 2017$ & $\begin{array}{l}\text { Tania Edith } \\
\text { Pariona Tarqui, } \\
\text { Indira Isabel } \\
\text { Huilca Flores } \\
\text { y Alberto } \\
\text { Quintanilla } \\
\text { Chacón } \\
\text { Grupo } \\
\text { Parlamentario } \\
\text { Nuevo Perú }\end{array}$ & $\begin{array}{l}\text { Proyecto de ley para } \\
\text { fortalecer la sanción penal } \\
\text { frente a los delitos contra } \\
\text { la libertad e indemnidad } \\
\text { sexual }\end{array}$ & $\begin{array}{l}\text { "Artículo 2.- Modificación de los artículos del } \\
\text { Código Penal: } \\
\text { Modifiquense los artí́culos } 80,170,171,172, \\
173,173-A, 174,175,17,176-\mathrm{A}, 177,178 \\
\text { y 178-A del Código Penal en los siguientes } \\
\text { términos: } \\
\text { "Artículo 80.- Plazos de prescripción de la } \\
\text { acción penal } \\
\text { La acción penal prescribe en un tiempo igual } \\
\text { al máximo de la pena fijada por la ley para el } \\
\text { delito, si es privativa de libertad. } \\
\text { En caso de concurso real de delitos, las } \\
\text { acciones prescriben separadamente en el plazo } \\
\text { señalado para cada uno. } \\
\text { En caso de concurso ideal de delitos, las } \\
\text { acciones prescriben cuando haya transcurrido } \\
\text { un plazo igual al máximo correspondiente al } \\
\text { delito más grave. } \\
\text { La prescripción no será mayor a veinte años. } \\
\text { Tratándose de delitos sancionados con pena de } \\
\text { cadena perpetua se extingue la acción penal a } \\
\text { los treinta años. } \\
\text { En los delitos que merezcan otras penas, la } \\
\text { acción prescribe a los dos años. } \\
\text { La acción penal es imprescriptible } \\
\text { tratándose de los delitos regulados en los } \\
\text { artículos 153, 153-A, 153-B y en los capítulos } \\
\text { IX, X y XI del Título IV, Libro segundo del } \\
\text { Código Penal”". }\end{array}$ \\
\hline 13 & 2115/2017-CR & $09 / 11 / 2017$ & $\begin{array}{l}\text { César Henry } \\
\text { Vásquez Sánchez } \\
\text { Grupo } \\
\text { Parlamentario } \\
\text { Alianza para el } \\
\text { Progreso-APP }\end{array}$ & $\begin{array}{l}\text { Ley que aumenta las penas } \\
\text { privativas de libertad e } \\
\text { incorpora la sanción de } \\
\text { castración química como } \\
\text { complementaria para } \\
\text { delitos de violación sexual }\end{array}$ & $\varnothing$ \\
\hline 14 & $2119 / 2017$ & $10 / 11 / 2017$ & $\begin{array}{l}\text { Janet Emilia } \\
\text { Sánchez Alva } \\
\text { Bancada Peruanos } \\
\text { por el Kambio }\end{array}$ & $\begin{array}{l}\text { Ley que incrementa las } \\
\text { penas de los delitos de } \\
\text { violación de la libertad } \\
\text { sexual previstos en el } \\
\text { capítulo ix del código } \\
\text { penal }\end{array}$ & $\varnothing$ \\
\hline
\end{tabular}



e indemnidad sexual en el perú

The imprescriptibility of crimes against freedom

and sexual indemnity in peru

\begin{tabular}{|c|c|c|c|c|c|}
\hline \multicolumn{6}{|c|}{$\begin{array}{l}\text { 9. ANEXO ÚNICO: PROYECTOS DE LEY QUE JUSTIFICARON LA INTRODUCCIÓN DE LA } \\
\text { IMPRESCRIPTIBILIDAD PARA EL DELITO DE AGRESIONES SEXUALES Y CONEXOS }\end{array}$} \\
\hline N. & $\begin{array}{l}\text { PROYECTO } \\
\text { DE LEY }\end{array}$ & FЕСНА & CONGRESISTA & TÍTULO & REFORMA \\
\hline 15 & 2165/2017-CR & $28 / 11 / 2017$ & $\begin{array}{l}\text { Maritza Matilde } \\
\text { García Jimenez }\end{array}$ & $\begin{array}{l}\text { Proyecto de ley que } \\
\text { aumenta las penas } \\
\text { privativas de la libertad } \\
\text { en la violación sexual y } \\
\text { violación sexual de menor } \\
\text { de edad, modificando } \\
\text { los artículos } 170^{\circ}, 173^{\circ} \\
\text { y adicionando el artículo } \\
\text { 173-b del código penal }\end{array}$ & $\varnothing$ \\
\hline 16 & 2258/2017-CR & $14 / 10 / 2017$ & $\begin{array}{l}\text { RICHARD ARCE } \\
\text { CÁCERES } \\
\text { G r u p o } \\
\text { Parlamentario } \\
\text { Nuevo Perú. }\end{array}$ & $\begin{array}{l}\text { Ley que amplía los plazos } \\
\text { de prescripción para los } \\
\text { delitos contra la libertad } \\
\text { sexual y otros a menores } \\
\text { de edad; y que modifica } \\
\text { el artículo } 82 \text { del código } \\
\text { penal }\end{array}$ & $\begin{array}{l}\text { Inicio de los plazos de prescripción } \\
\text { Artículo 82.- Los plazos de prescripción de } \\
\text { la acción penal comienza: } \\
\text { 1. En la tentativa desde el día en que cesó la } \\
\text { actividad delictuosa; } \\
\text { 2. En el delito instantáneo, a partir del día en } \\
\text { que se consumó; } \\
\text { 3. En el delito continuado, desde el día en que } \\
\text { terminó la actividad delictuosa; y } \\
\text { 4. En el delito permanente, a partir del día en } \\
\text { que cesó la permanencia; } \\
\text { Para los delitos previstos en el Capítulo IX } \\
\text { del Título IV, Libro Segundo del presente } \\
\text { Código siempre que la víctima sea menor de } \\
\text { edad; la prescripción de la acción penal inicia } \\
\text { cuando alcance la mayoría de edad y realice } \\
\text { la respectiva denuncia ante las instancias } \\
\text { correspondientes. }\end{array}$ \\
\hline
\end{tabular}




\begin{tabular}{|l|l|l|l|l|l|}
\hline \multicolumn{2}{|c|}{ 9. ANEXO ÚNICO: PROYECTOS DE LEY QUE JUSTIFICARON LA INTRODUCCIÓN DE LA } \\
IMPRESCRIPTILIDAD PARA EL DELITO DE AGRESIONES SEXUALES Y CONEXOS
\end{tabular}


La imprescriptibilidad de los delitos contra la libertad

e indemnidad sexual en el perú

The imprescriptibility of crimes against freedom

and sexual indemnity in peru

\begin{tabular}{|c|c|c|c|c|c|}
\hline \multicolumn{6}{|c|}{$\begin{array}{l}\text { 9. ANEXO ÚNICO: PROYECTOS DE LEY QUE JUSTIFICARON LA INTRODUCCIÓN DE LA } \\
\text { IMPRESCRIPTIBILIDAD PARA EL DELITO DE AGRESIONES SEXUALES Y CONEXOS }\end{array}$} \\
\hline N. & $\begin{array}{l}\text { PROYECTO } \\
\text { DE LEY }\end{array}$ & FECHA & CONGRESISTA & TÍTULO & REFORMA \\
\hline 19 & 2402/2018-CR & $07 / 02 / 2018$ & $\begin{array}{l}\text { Lucio Ávila Rojas } \\
\text { Grupo } \\
\text { Parlamentario } \\
\text { Fuerza Popular }\end{array}$ & $\begin{array}{l}\text { Proyecto de ley que } \\
\text { modifica el artículo } 170 \\
\text { del Código Penal a fin } \\
\text { incrementar la pena base } \\
\text { del delito de violación } \\
\text { sexual, hacerla extensiva } \\
\text { a todo el personal } \\
\text { académico y establecer la } \\
\text { cadena perpetua cuando se } \\
\text { cause la muerte o cuando } \\
\text { el agente le quita la vida } \\
\text { a la víctima para ocultar } \\
\text { su delito, así mismo se } \\
\text { modifica el artículo } 170 \text { a } \\
\text { fin de imponer como pena } \\
\text { única la cadena perpetua } \\
\text { cuando la víctima tenga } \\
\text { menos de } 14 \text { años de } \\
\text { edad, y establece la } \\
\text { inhabilitación definitiva } \\
\text { en los delitos previstos en } \\
\text { los artículos } 170,171,172 \\
\text { y } 174 \text { del código penal } \\
\text { cuando el agente ejerce } \\
\text { cargo público, además } \\
\text { establece la castración } \\
\text { química como medida de } \\
\text { seguridad complementaria } \\
\text { y busca la inaplicación } \\
\text { de la figura legal del } \\
\text { error de comprensión } \\
\text { culturalmente } \\
\text { condicionado cuando } \\
\text { se trate de delitos de } \\
\text { violación sexual en } \\
\text { agravia de menores de } \\
\text { edad. }\end{array}$ & $\varnothing$ \\
\hline 20 & 2415/2018-CR & $13 / 02 / 2018$ & $\begin{array}{l}\text { Lourdes Alcorta } \\
\text { Suero } \\
\text { Grupo } \\
\text { Parlamentario } \\
\text { Fuerza Popular } \\
\end{array}$ & $\begin{array}{l}\text { Ley que establece la pena } \\
\text { de cadena perpetua para el } \\
\text { delito de violación sexual } \\
\text { de menor de catorce años }\end{array}$ & $\varnothing$ \\
\hline 21 & 2416/2018-CR & $13 / 02 / 2018$ & $\begin{array}{l}\text { Lourdes Alcorta } \\
\text { Suero } \\
\text { Grupo } \\
\text { Parlamentario } \\
\text { Fuerza Popular }\end{array}$ & $\begin{array}{l}\text { Ley que prohibe la } \\
\text { revisión de la pena de } \\
\text { cadena perpetua en caso } \\
\text { de violación sexual de } \\
\text { menores de edad }\end{array}$ & $\varnothing$ \\
\hline 22 & 2420/2018-CR & $14 / 02 / 2018$ & $\begin{array}{l}\text { Rogelio Robert } \\
\text { Tucto Castillo } \\
\text { G r u p o } \\
\text { Parlamentario } \\
\text { "Frente Amplio } \\
\text { por Justicia, Vida } \\
\text { y Libertad" }\end{array}$ & $\begin{array}{l}\text { Ley que crea el registro de } \\
\text { condenados por delitos de } \\
\text { violación sexual }\end{array}$ & $\varnothing$ \\
\hline
\end{tabular}


9. ANEXO ÚNICO: PROYECTOS DE LEY QUE JUSTIFICARON LA INTRODUCCIÓN DE LA IMPRESCRIPTIBILIDAD PARA EL DELITO DE AGRESIONES SEXUALES Y CONEXOS

\begin{tabular}{|c|c|c|c|c|c|}
\hline N. & $\begin{array}{l}\text { PROYECTO } \\
\text { DE LEY }\end{array}$ & FЕСНА & CONGRESISTA & TÍTULO & REFORMA \\
\hline 23 & 2485/2017-CR & $05 / 03 / 2018$ & $\begin{array}{l}\text { César Villanueva } \\
\text { Arévalo, Marisol } \\
\text { Espinoza Cruz y } \\
\text { otros } \\
\text { Grupo } \\
\text { Parlamentario } \\
\text { Alianza para el } \\
\text { Progreso }\end{array}$ & $\begin{array}{l}\text { Ley que modifica el } \\
\text { artículo } 170,173 \text { y } \\
173 \text {-A del código penal } \\
\text { para agravar las penas } \\
\text { y restringir beneficios } \\
\text { penitenciarios en los casos } \\
\text { de violación sexual de } \\
\text { menor de edad }\end{array}$ & $\begin{array}{l}\text { "Artículo 173-A.- Violación sexual de menor } \\
\text { de edad seguida de muerte o lesión grave } \\
\mathrm{Si} \text { el acto previsto en el inciso } 2 \text { del artículo } \\
\text { anterior causa la muerte de la víctima o le } \\
\text { producen lesión grave o si el agente procedió } \\
\text { con crueldad, la pena será de cadena perpetua. } \\
\text { En estos casos no procede la prescripción, el } \\
\text { indulto, ni la conmutación de pena ni el derecho } \\
\text { de gracia a los sentenciados por este delito } \\
\text { contra los menores de edad, ni los beneficios } \\
\text { penitenciarios de redención de la pena por } \\
\text { el trabajo y la educación, semi-libertad y } \\
\text { liberación condicional". }\end{array}$ \\
\hline 24 & 3008/2017-CR & $12 / 06 / 2018$ & $\begin{array}{l}\text { Modesto Figueroa } \\
\text { Minaya }\end{array}$ & $\begin{array}{l}\text { Ley que incorpora la } \\
\text { imprescriptibilidad en la } \\
\text { comisión del delito de } \\
\text { trata de personas con fines } \\
\text { de explotación sexual y/o } \\
\text { laboral cuando la víctima } \\
\text { es menor edad. }\end{array}$ & $\begin{array}{l}\text { "Artículo } 1^{\circ} \text {.- Objeto de ley } \\
\text { Incorporar al Código Penal la } \\
\text { imprescriptibilidad del delito de trata de } \\
\text { personas con fines de explotación sexual y/o } \\
\text { laboral cuando la víctima es menor de edad. } \\
\text { Artículo } 2 .- \text { Adiciónese al artículo } 80^{\circ} \text { el } \\
\text { siguiente párrafo final establecido. } \\
\text { La acción penal prescribe en un tiempo igual } \\
\text { al máximo de la pena fijada por la Ley para el } \\
\text { delito, si es privativo de la libertad. } \\
(\ldots) \\
\text { En el delito de trata de personas con fines } \\
\text { de explotación sexual y/o laboral cuando la } \\
\text { víctima es menor de edad, la acción penal es } \\
\text { imprescriptible". }\end{array}$ \\
\hline
\end{tabular}

Fuente: Elaboración propia 